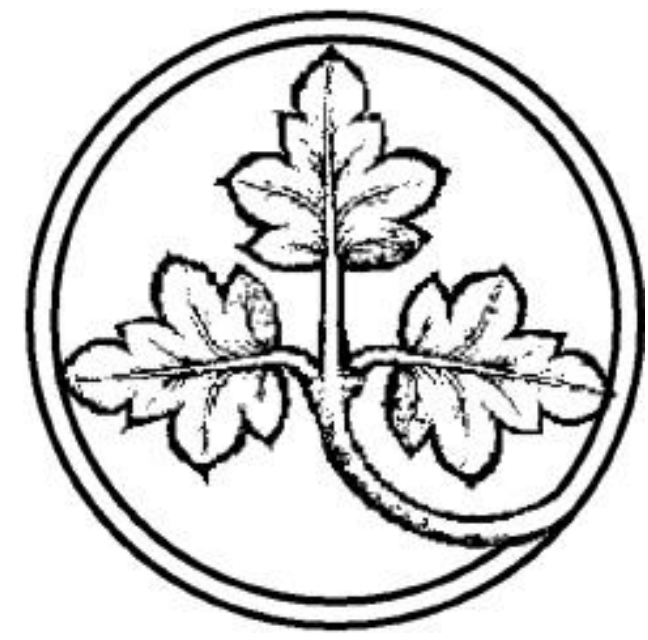

Gemeinschaftsgüter: Recht, Politik und Ökonomie

\author{
Preprints \\ aus der Max-Planck-Projektgruppe \\ Recht der Gemeinschaftsgüter \\ Bonn \\ 2000/12
}

Overt and Covert

Institutionalization in Europe

VOn

Adrienne Héritier 


\title{
Overt and Covert Institutionalization in Europe
}

\author{
Adrienne Héritier
}

June 2000

Max-Planck-Projektgruppe Recht der Gemeinschaftsgüter, Poppelsdorfer Alle 45, 53115 Bonn

www.mpp-rdg.mpg.de 


\section{Overt and Covert Institutionalization in Europe}

\section{Introduction}

Observers of the European policy-making process are inevitably struck by the contrast between cumbersome decision-making processes on the one hand and simultaneous swift policy developments on the other. Many policies seem to be stuck for long periods in the Council, while at the same time similar measures are introduced under a different guise along a different path. A case in point is European anti-poverty policy. At the very time when this measure was bogged down in a Council deadlock, it was reintroduced by the Commission, couched in different terms in a new political context. In the end it was elevated to official status in the Amsterdam Treaty. A further example of a similar process was in European telecommunications policy which initially met with strong resistance from member states. As a result of the Commission's skilful use of all kinds of soft measures, such as offering research funds to industry and actively creating a supportive policy network, it finally became established as a regular European policy. ${ }^{1}$ Or, to cite an example from general procedure: the main avenue of European policy-making in the Council often stalls because of the need for consensus, whereas Court rulings and Commission decisions are not hindered by this requirement. Consequently, the emphasis of European policy expansion has often shifted to the European Court of Justice's and the Commission's legal interpretation of rules which exist under the Treaty of Rome. This has given European policies a bias in favour of free trade and free competition (Scharpf 1999). At the same time market-correcting measures and the pursuit of distributive goals remain entangled in the gridlock of Council decision-making processes and are pushed into the background. Again, however, they reemerge in bits and pieces and under a different guise in new contexts as a result of successful circumvention of Council deadlocks (Héritier 1999). Why is it that European policies which stagnate in the main political arena, materialize in other shapes and forms elsewhere? And what are the typical escape routes when the main political avenue is blocked? I argue that the formal institutional structure of the European Union together with the diversity of member states' interests would regularly lead to an impasse in decision-making were it not for the existence of different paths of institutionalization which have emerged to circumvent impending deadlock. This overt and covert institutionalization creates a European political space, meaning "a widely shared system of rules and

This was not exclusively the result of the application of informal soft measures, but also of the use of Article 90,3 by the Commission, which was subsequently confirmed by the ECJ (Héritier 1999). 
procedures to define who actors are, how they make sense of each other's actions and what types of actions are possible" (Stone Sweet, Fligstein, Sandholtz: introduction to this volume, p.20). It has developed in three different ways; firstly, straightforward changes made to existing rules as a result of intepretation and negotiated modifications; secondly, the explicit and implicit development of new soft or informal institutions, such as information and monitoring, mobilization and network building, and the spontaneous emergence of social conventions, as a way of expanding the areas of European activity; and thirdly, "kitchen politics", i.e. more covert ways of overcoming formal institutional obstacles to decision-making. Such covert ways involve committing actors to policy decisions, the implications of which are not spelt out in advance, by concealing planned or on-going changes from the general public, as well as by re-labeling and re-contextualizing issues in order to embed them in a different choice situation which helps overcome a deadlock. These three different modes of effecting change - as will be shown in the following - can be observed in the most diverse areas of European policy-making and generally result in a widening of European policy activities. They constitute the ways in which the rule structures governing the European policy space are elaborated, or adapted, through interpretation, legislation, the development of shared understandings of norms and procedures, but also by committing unwitting actors to a subsequent widening of European activities: they are is the central theme of this volume as indicated in the introductory essay by Stone, Fligstein, and Sandholtz. Since modes of institutionalization where there is member-state resistance to the introduction of more European activities are of particular interest in this article, by logical implication the question also arises as to the conditions under which deepening institutionalization does not occur, and a development in the opposite direction takes place, narrowing the scope of European activities. In other words, the systematic points where turns in the other direction occur - steps of deinstitutionalization, as it were - have to be identified as well. This chapter is divided into two sections: first, the three basic modes of overt and covert institutionalization and their theoretical foundations are discussed, each illustrated by empirical examples of European policy-making. In the second stage the question is raised as to consequences of the different modes of institutionalization and the conditions under which these different paths of deepening European institutionalization do not normally occur.

\section{Sources and Modes of Overt and Covert Institutionalization: Theoretical Interpretation and Empirical Examples}

The starting point of the argument is that the diversity of member states' interests together with the primary formal institutions create the necessity for consensus which very often is not reached. Instead, a deadlock situation emerges in the main political arena, the Council - a joint-decision trap (Scharpf 1998). This is a formal decision-making setting where the consensus or unanimous vote of all the representatives of the sub-units of a polity are needed to bring about a decision. As a consequence the decision-making process tends to stall. At the same time there are no exit options open for leaving the polity either. The necessity for consensus in the Community derives from the fact that the formal institutions of the polity have been constructed in such a way as to preserve the 
diversity of member states which wish to safeguard their sovereignty. In other words, the founding member states established a decentralized and fragmented polity that gives individual members the power of veto but does not have a strong central power for coordinating its various decision-making bodies: actors and institutions are linked by increasingly complex rules in the legislating process. This aspect of institutional development may well be accounted for by the claim that the new European institutional arrangements were negotiated with regard to their likely distributional impacts (Knight 1992; Knight 1995). The specific institutional impacts at stake here are decision-making competences and sovereignty which the European supranational institutions would have taken over had they been granted significant and well-defined powers, a step which member states were reluctant to take. Hence the founding member states deliberately created an institutional structure whose central decision-making powers lie with an intergovernmental body, the Council of Ministers, whose Parliament is relatively weak, and whose decision-making process is contingent on the simultaneous agreement of several institutions, making it a rather unwieldy and cumbersome process. However, by establishing such a complex and fragmented decision-making structure the founding members inadvertently created a power vacuum into which some actors moved, applying strategies of overt and covert institutionalization to overcome the frequent decision-making deadlocks; in particular in our case, these were an entrepreneurial Commission and the European Court of Justice. Another related source of overt and covert institutionalization results from the lack of specific detailed rules in the original Treaty about how to deal with all kinds of future contingencies. Instead, - often as a result of a compromise between conflicting interests - the rules of the Treaty of Rome and all subsequent treaties provide latitude in the application of rules and competences which has to be interpreted when applied to a new context. These possibilities may be exploited by entrepreneurial actors in order to achieve their goals.

The various overt and covert modes of deepening institutionalization deployed in the light of these possibilities can be best explained by a variety of theoretical viewpoints: institutions whose rules and basic goals are defined constitute the starting point of the analysis. The first mode of deepening institutionalization - the straightforward modification through interpretation and bargained change of existing rules which had been established to maintain the existing distribution of competencies (consensus rule) (Knight 1992) - may be accounted for by theories which describe the exploitation of existing formal institutions by organizational entrepreneurs (North 1995) or by skilled social actors (Fligstein, in this volume). Thus the specification of vague primary rules may bring about a change. Similarly the theory describing the development of dyadic and triadic governance based on third party dispute resolution accounts for the generation and modification of institutional rules (Stone Sweet 1999). Further, principal agent theory or the modified trustee scheme of independent non-majoritarian institutions (Majone 1998) explicates how agents or trustees (the Commission or the ECJ) gain latitude if the contending principals (the member states) have created ambiguous rules which are open to interpretation (Marks, Hooghe, Blank 1996; see also Sandholtz, Stone Sweet 1998). Straightforward institutionalist change through negotiated agreements has been extensively theorized in bargaining theory, explicating how gridlock is overcome by forming compromises, striking package deals, or paying compensation. The second path of overt institutionalization, deploying soft instruments of information and monitoring as well as mobilization and network building, and the 
emergence of social conventions, is described by the theory of regulation through publication (Majone 1995) and network theory (Mayntz 1993), and the theory of the spontaneous emergence of institutions (Calvert, Johnson 1998), respectively. The third covert mode of institutionalization, i.e. committing actors and concealing decision-making making processes as well as re-contextualizing, may be explained by sociological organization theory which points out that decision-making processes are frequently as much concerned with creating actors' commitment as they are with rationally weighing the costs and benefits of specific decisions, and how, by isolating decisions from the wider political decision-making process, policy changes may be brought about (Brunsson 1989). Finally, the practice of re-labeling issues has been discussed in policy analysis as a mode of enhancing their chances of acceptance in the political arena (Windhoff-Héritier 1987, Riker 1996).

\section{Overt and Formal Modes of Changing Rules}

\section{The Formal Interpretation of Rules}

Treaties are negotiated in interstate bargaining processes in which each state government has the power of veto over the content of the agreement. This is an invitation to ambiguity on points of contention "to allow each participating government to claim success in representing national interests" (Marks, Hooghe, Blank 1996:354). As a consequence, once primary rules are enacted, they often do not clearly delineate the assignment of powers and responsibilities for all categories of future issues and situations (Calvert, Johnson 1998). This is one reason why existing rules need to be clarified and interpreted (Shapiro, in this volume). They are thereby modified and as such become the guidelines for subsequent action. The process of rule generation and alteration has also been conceived of as the emergence of governance through dyadic and then triadic governance with third party dispute resolution (TDR) (Stone Sweet 1999; Stone Sweet and Caporaso 1998). It may come about as a result of mutual agreement and delegation of authority to a third party, or on a compulsory basis through jurisdiction. The conflicts around a rule are adjudicated and the rules of adjudication discussed and elaborated in such a way as to develop a normative structure which subsequently guides conflict solution. "TDR generates a discourse about how people ought to behave. Because rules, reasoning about rules, and the adaptation of rules to specific social needs constitute the core of this discourse....precedent follows naturally. Precedent helps to legitimize TDR by simultaneously acknowledging rule-making behavior, while constraining that same behaviour with a rule: that like cases shall be settled likewise" (Stone Sweet 1999:157). At the end of this process "we find ourselves in a rather different world" (Stone Sweet 1999:158). Vague primary rules will also be exploited, applied and interpreted by entrepreneurial actors in ways that best fit their own particular agendas, with all actors seeking to enhance their respective sphere of activities. By investing in the acquisition of knowledge and the co-ordination of skills, they gradually learn how to wield more power in policymaking and in so doing gradually alter institutions and may produce results which differ from these intended by the designers of the formal institutional structure (Fligstein 1997; North 1995). 
In the European context, with its complex and interlinked decision-making structure, it has been the Commission and the European Court of Justice in particular which, by means of clarification and adjudication, have specified interpretable formal rules and mediated between conflicting actors to overcome policy stalling. The Court acts as arbiter in decisional conflicts, interpreting and specifying rules which then serve as reference points for future decision-making (Stone Sweet, Brunell 1998). Thus, the ECJ has constantly defined and redefined such concepts as "market control" and "market share" in interpreting statutes, regulations and derogation clauses, thereby significantly contributing to the creation of a regional European integrated market (Egan 1998; Shapiro 1968). The Commission has also struggled to determine exactly what constitutes an "equivalent to a quantitative trade barrier", the latter being prohibited under the Treaty of Rome (Art. 30). One of the most important policy consequences of overt institutional change through rule interpretation by the Commission and the Court has been the dominance of negative integration over positive integration (Scharpf 1999). Negative integration, i.e. market-creating measures, have relied on judicial lawmaking and Commission decisions based on the competition principle which is embedded in the Treaty of Rome, by-passing the Council (such as under Art.90,3). By contrast, positive integration, or market-correcting policies have to rely on the consensual capacity of the Council, and more and more on the European Parliament, which have to overcome considerable hurdles. These are particularly great when it comes to highly politically-visible, redistributive issues. Thus close observation of market integration has become the overarching principle of European policy-making as a result of non-majoritarian decisions, e.g. judicial law-making, and Commission decisions. This policy has been extended, "without much political attention, through interventions of the European Commission against infringements of Treaty obligations, and through the decisions and preliminary rulings of the European Court of Justice" (Scharpf 1999:51) The doctrines of "direct effect" and "supremacy" have brought about the "constitutionalization of competition law" (Scharpf 1999:54).

\section{Formal Change through Bargaining}

Existing institutional rules are constantly being adjusted to meet the requirements of new circumstances, not just by judicial interpretation but also through direct renegotiation. These new political bargaining processes are largely conducted with regard to their distributional effects. However, the process of deliberation and the exchange of views which accompany it may produce new information and may alter the participants' basic preferences (Calvert, Johnson 1998:17). At least such deliberation is helpful in establishing a common understanding of what is at stake (Knight, Johnson 1994), but most likely even after deliberation, "people will continue to disagree in good faith about the common good, and about the issues of policy, justice and right" (Waldron 1996:2189 quoted in Calvert, Johnson 1998:17). Conflicting interests regarding the "right" interpretation of a rule will remain, with each participant seeking to achieve solutions to his or her own advantage. However, throughout the process, arguments which are accepted by the majority are those which will influence future rule interpretations (Calvert, Johnson 1998). They become principles that legitimize policy decisions and "are likely to remain acceptable, and thus to remain influential in policy making, 
tomorrow" (Calvert, Johnson 1998:31). As such they are used by politicians and courts as a means of supporting their position in resolving the interpretation of a rule.

While deliberation may clarify the order of preferences of the actors involved and the nature of the conflict at stake, as well as create "legitimate" arguments which can be used as a resource, divergent interests nevertheless still have to be accommodated if deadlock is to be avoided. This may be achieved by arriving at package deals or issue-linkages: measures from which the losers of the contested, proposed policy stand to gain, are added to the "focus issue" in order to win the opponent over. Losers may also be offered compensation in return for their support. Another way of settling conflicts is to only pass framework solutions, which leaves all parties free to shape the respective policy in more detail as they choose. The Commission frequently acts as broker and prepares such deals and solutions. It surveys all on-going policy developments and is engaged in multiple negotiation arenas. With its intimate knowledge of the complicated institutional rules it is able to exploit this information and seize opportunities to act in overcoming decisional deadlocks.

A recent example of how a redistributional conflict was resolved and a policy impasse avoided in an institutional context requiring unanimous decision-making is the compromise struck in the reform of the regional funds policy. Reform of the regional aid package was long overdue. In particular the prospect of the Central and Eastern European countries joining the EU put pressure on the Commission to speed up reform. Many parts of the present Union which currently receive regional aid - intended for the poorest areas - will loose it before the enlargement takes place. Individual member states have naturally sought to retain their share of EU structural funds. The conflict has been resolved by letting member states deal with potentially difficult questions: by invoking the subsidiarity principle the unpleasant decision as to which regions were to be denied aid has been passed over to national governments. The former objective 1 regions (i..e. regions whose development is considered to be 'lagging behind' the EU average) also receive 'transitional support' over the next five years. The 'phase-out' assistance which will be made available in progressively diminishing amounts is designed to soften the blow (European Voice, 27.1 - 2.2.2000, p.12).

A case of institutional competences being renegotiated when threatened by impending deadlock could recently be observed in the Commission and the European Parliament. Under the Amsterdam Treaty the Parliament has to confirm the new composition of the Commission in its entirety. During its hearings of the new commissioners, the Parliament disapproved of individual candidates. It then secured a promise from the President of the Commission that - in return for Parliamentary support for the entire team - the President would in future dismiss individual commissioners who no longer enjoyed the support of the Parliament (SZ 8.9.1999). Thus, the European Parliament gained de facto the right of a vote of confidence vis-à-vis individual commissioners (SZ 15.9.1999).

The first two modes of explicit formal change of the primary institutional rules of the Community are well known and constitute the central focus of political science research on Europe. This is not the case for the two remaining modes: the overt, informal soft strategies and the more covert ways of changing existing rules. 


\section{Overt Change through Informal Strategies and Patterns}

The second basic mode of overcoming policy-making gridlocks by developing informal overt and covert institutions is the establishment of soft institutions or informal rules. The existing formal institutions are thereby modified and a decisional impasse may be circumvented. The introduction of soft rules may take the shape of an explicit intentional strategy, such as information/shaming/monitoring and network building, or a spontaneous, decentral co-ordination (Demsetz 1988).

\section{Exchange of Information, Naming and Shaming, Monitoring}

The purpose of the exchange of information is to prepare the first stage of a Community policy. Initially member states only provide mutual information, which is subsequently followed by binding regulatory measures. "Naming and shaming" is used after member states have provided information about their activities in the context of monitoring. It implies the attempt to change the behaviour of regulatees by exposing their behaviour if sanctioning tools are not readily available for the regulator, as is often the case in Europe.

The recent Amsterdam Treaty chose the first path in the initial stages of a common labour market policy. A number of member states, such as Britain and Germany, opposed the introduction of explicit European competences to create employment, while France, Italy and some other member states were in favour. The way round the deadlock was the introduction of unemployment policy as a soft programme with each country reporting annually on the development of its employment figures, the measures taken to reduce unemployment and the mode of monitoring the development; sharing experience in the field of fighting unemployment was also promoted. Another example of the Commission using this soft method of introducing a new policy is in telecommunications and research and technology policy. The attempt to establish a European policy had met with the resistance of member-state governments. Hence the Commission sought new means: it introduced business round tables to facilitate regular exchanges of information and opinions and offered research funds which could be used on a voluntary basis to push national governments' policy in a new direction. In the end it succeeded in establishing a European telecommunications and research and technology policy.

In order to compensate for its lack of formal powers for ensuring that member states comply with Community policy, such as in regional policy and environmental policy, the Commission frequently attempts to gain control of implementation by publicizing implementation details. Member states have to provide information about the activities they have undertaken with regional funds money, and in the case of environmental policy, they have to publish emission data on water and air quality. The Commission highlights this by publishing this information as performance tables in order to shame governments into compliance. It also organizes campaigns to inform citizens about their rights vis-àvis national administrations under Community legislation, such as by guaranteeing access to information on the environment held by national administrations. It thereby gains information on the quality of implementation of Community legislation. These routine measures have subsequently been formalised by the Access to Information Directive in environmental policy. 
Network building and mobilization may be used by the Commission by empowering domestic actors such as ministries and interest groups and large firms, to differing degrees. Cleavages in the domestic political arenas are exploited and alliances formed with different actors in order to build support for a specific European policy measure when faced with an impending deadlock. The strategies of network building and mobilization used by the Commission may be illustrated by the example of anti-poverty policy (Bauer 1999). The Commission employed a variety of methods to circumvent the gridlock in the Council which was preventing the programme from being continued and extended. Ignoring the situation in the Council, the Commission proceeded to set up a separate programme to combat poverty and social exclusion. Applications were invited. In a very short time the Commission received more than 2000 bids, a sizeable number of which were from precisely those countries whose governments were most opposed to the programme (Germany, Britain), and quickly initiated 86 demonstration programmes. An entire network of actors with a stake in the poverty programme was created. To strengthen the network the Commission mobilized Non Governmental Organizations on an International Day to Eliminate Poverty and raised support for European competences to fight poverty. Britain, supported by Germany and Denmark went to the Court of Justice claiming that the Commission was spending money "illegally" and without authorization. The Court of Justice ruled that "Contrary to what the Commission has argued, the purpose of the projects ...was not to prepare future Community action or launch pilot projects. Rather, it is clear from the activities envisaged, the aims pursued and persons benefitted that they were intended to continue the initiatives of the Poverty 3 Programme, at a time when it was obvious that the Council was not going to adopt the Poverty 4 proposal, which sought to continue and extend Community action to combat social exclusion" (C106/96 judgement 12.5.1998).

The Commission also engages in network building in order to build up an informal capacity in implementation. By establishing links with sub-national public and private actors, as mentioned above, it seeks to obtain information on implementation performance such as in environmental policy where subnational actors are explicitly solicited to supply information to the Commission regarding implementation practices (Héritier, Knill, Mingers 1996).

\section{Spontaneous Co-ordination}

The other type of informal rules emerges decentrally and spontaneously as social conventions. Here, strategic uncertainty about others' preferences promotes behaviour that resolves a collective action dilemma. It makes sense to shape the other actors' perceptions of one's preferences and to give signals that you are willing to co-operate and willing to trust. These signals enable the like-minded to locate others who are trustworthy, who in turn can build up a reputation for responding cooperatively to trust (Bates 1988). Because actors prefer co-ordination as one of the co-operative outcomes, as opposed to non-co-ordination, they will use whatever salient information they have 
(focal point) in order to achieve it (Schelling 1963). In time more actors will follow suit, and a social convention is established which provides information about the future actions of others (Knight 1995).

A well known example of the decentralized development of such a social convention which enables the policy process to move on is the rule of diffuse reciprocity in the Council of Ministers. It is an informal mechanism which ensures that the interests of one member state are not blatantly disregarded when conflicts are settled, because every country is aware that on some future occasion it may be the one in the minority. COREPER (the Committee of Permanent Representatives), for example, has developed a peer-consciousness that is oriented towards the notion of fairness and maintains a focus on future concessions (Héritier 1997). An institutionalized preference for cooperation has emerged. There is a belief that all participants will profit in the long-term, since offending one another's interests in an outspoken way would make future retributions likely (Schmidt 1995). And since member states are highly likely to stay together under the common roof of the European Union, they are well advised to establish a fair balance between all the actors concerned.

\section{Covert Institutionalization}

Finally, there is a more covert mode of playing with the formal institutional rules in order to bring about change which is more indirect in the sense that conflictual issues are not fully revealed with all their implications. One mode is to commit actors at an early stage, a different mode is to shape policy behind closed doors in such a way as to make it difficult for those subsequently responsible for formal decision-making to unravel the decisions reached. And finally, in order to avoid deadlock decisions are re-labelled and fitted into a new context of policy making so as to win the support of decisionmakers. As a representative of the Commission put it: "We all know that agricultural policy needs to be reformed. But it is so much more difficult to achieve this by putting it explicitly on the agenda" (Information Member of the Commission at ECSA, 1997) ${ }^{2}$. These more indirect, indeed devious modes of overcoming deadlock by institutionalization are well described by sociological organization theory (see for instance Brunsson 1989) which analyzes how organizations seek to deal with conflicting expectations in their environment by committing actors to a decision in principle, where they are not fully aware of the implications and potential conflicts. In terms of participatory scope, the organizational leaders also seek to avoid stalling by isolating a larger number of actors from the decision-making process. Complex decisions are wrapped up "behind closed doors" in such a way that they are difficult to unravel at a later stage when more actors are allowed to participate in the decision-making. The strategy of re-labelling or redefining issues, such as to link them up other, popular, issues, has been elaborated in policy analysis (Windhoff-Héritier 1987).

$2 \quad$ ECSA: European Community Studies Association, Seattle, 1997. 


\section{Committing Actors}

Organization theory draws attention to the fact that decision-making is not only about choice, but also about commitment. Decisions may be made primarily to secure the support of actors and to create motivation and expectations which encourage participants to pledge themselves to a specific action. Once the commitment of the actors is secured, the organizational action can be mobilized (Brunsson 1989). The prime intention here is to reduce the uncertainty about actors' behaviour rather than the uncertainty about the content and consequences of alternatives. "Preferences are adapted .... motivation and expectation attaching to a specific action are promoted" (Brunsson 1989:179).

We are quite often faced with this unofficial "under-cover" mode of institutional development in a deadlock-prone polity such as the European Union. An example where the introduction of a new institutional rule unavoidably triggered further extensive institutional changes of which the actors were initially unaware, was the decision to establish monetary union, which has been termed a Trojan horse in European policy making. It exerts pressure on all involved to introduce, in addition, a common monetary policy and fiscal policy, together with the deregulation of financial markets. In other words there are long-term policy implications and spill-over effects which were not the explicit objectives of all the actors who explicitly acquiesced to the initial decision at the Maastricht conference. As Germany's former chancellor Kohl put it, monetary union is synonymous with the rise of Europe and is an auxiliary device (Notaggregat) for necessary European reforms (SZ, 12.9.1999).

A further example of a precise and extensive institutional commitment being created without the actors involved being fully aware of what they committed themselves to, is the 1982 Framework Directive on Industrial Installations. Although this directive initiated the Commission's important change in strategy from a quality-oriented to an emission-based policy the decision-making process proved surprisingly unproblematic. The measure was adopted after only a year of negotiations - a very short period by EU standards. One reason for this was that the directive itself did not lay down special emission limits for pollutants, but was restricted to general procedural provisions for licensing industrial plants. The absence of statutory limits at the time of the negotiations possibly led some countries to misjudge the full consequences of the provisions. "We were astounded ourselves at how quickly the thing was dealt with. We'd never expected that it (the directive) would be adopted in less than a year. For me there's only one explanation: the member states didn't realize at the time what they were signing" (Interview with the EU Commission, DG XI, Sept 1993 - in Héritier, Knill and Mingers 1996:180).

\section{Secluded Decision-Making Processes}

Conflictual demands which are likely to end up in a decisional stalemate in open debate are often hived off into special organization units which sit down and hammer out decisions with the benefit of advice from experts. As a consequence, once such decisions have been reached, it is difficult to undo them at a later stage when the political debate is again opened up to a wider range of participants. This mode of under-cover institutional change is quite often the case in highly contested areas such as most recently in the attempt to hamonize the taxation of capital income where a specific working 
group was instituted for the purpose of producing proposals which could accommodate the objections of Britain and Luxembourg, or in complex technological fields of decision-making such as the Volatile Organic Compound Directive in environmental policy. By establishing specific policy working groups and networks in such questions, state executives give the Commission latitude to formulate very precise regulations. Here the Commission functions as a "hub of numerous highly specialized policy networks of technical experts designing detailed regulations" (Marks, Hooghe, Blank 1996:355).

\section{Re-labelling and Restructuring a Choice Situation}

By linking an issue with an issue which enjoys wide support, or by presenting the issue differently, its prospects of being accepted in the political arena may be improved, because new and compelling aspects are highlighted (Relabelling, Windhoff-Héritier 1987). A related strategy is to include alternatives into a choice situation in such a way that even the opponents of a measure are compelled by the structure of the situation to support it (heresthetics, Riker 1996). Actors' choices on the issue are altered. "And this is what heresthetics is about: structuring the world so you can win. For a person who expects to lose on some decision, the fundamental heresthetical device is to divide the majority with a new alternative, one the person prefers to the alternative previously expected to win" (Riker 1996:9).

Again the Commission's poverty programme provides an example of re-labelling and recontextualizing. By re-introducing the programme in the context of the European Social Fund, the Employment-INTEGRA Initiative, and concentrating on the integration of migrants, refugees, the homeless, lone parents, and ex-prisoners into the labour market, the programme was able to build on a new supportive coalition. The Commission thus shifted the focus from "more 'traditional', labour market integration strategies", which are the preserve of the member states, to the integration of marginal groups. In the end, the Commission succeeded in having a new Article 137(2) TEC (ex118(2)) incorporated into the Amsterdam Treaty: "The Council, acting in accordance with the same procedure (co-decision; A.H), may adopt measures designed to encourage co-operation between Member States through initiatives aimed at improving knowledge, developing exchanges of information and best practices, promoting innovative approaches and evaluation of experiences in order to combat social exclusion" (Bauer 1999:12/13).

Another case in point in re-contextualizing is the attempt by the Commission to present a labour contractual issue as a health and safety issue to be decided under qualified majority rule. By linking contractual rights to health and safety issues, which are decided according to the qualified majority rule of Art. 118a, it sought to outwit the British government which was vetoing the working-time measure. The British did not implement the directive and brought an action in the ECJ challenging its legal basis under QMR, arguing that the regulation of working time should not be linked to social (health and safety) issues. In 1996, the Court ruled that the directive had been adopted correctly on the basis of Art. 118a and called for a broad interpretation of the words 'working environment', 'safety' and 'health' using the definition of the World Health Organisation (Héritier 1999). 


\section{Conclusion: Consequences and Contradictions}

It has been argued that the consensual decision rules and the heterogeneity of member-state actors tend to lead to stalemate in decision-making. This deadlock situation is overcome by an overt and covert deepening of institutionalization. Three modes of overt and covert institutionalization have been distinguished here: the explicit and straightforward specifying and modification of existing formal rules by adjudication and negotiations; the formation of new informal soft rules and strategies; and the more indirect and covert methods of circumventing deadlock by committing actors in advance to decisions which have far-reaching consequences, by concealing delicate issues in secluded circles, and by fitting issues into a new policy context where their chances of being accepted are greater. Thus the primary institutions established in the 1950s have produced situations which have had consequences which none of the actors involved - who sought to influence the original institutional structures in line with their own interests - were able to foresee. Rather, the original formal structures have been creatively and strategically exploited to achieve rule innovation. Also, many elements of the structure now in place in the EC/EU, including much that is expressed in formal law, originated from outside the formal legislative process in informal processes, and was eventually incorporated into it (Sandholtz, Stone Sweet 1998).

Of course, the rules of any polity which open up repertoires of acceptable actions rather than determine behaviour are used creatively. However, I contend that, given the diversity of its members and their inability to agree on the direction in which the polity should develop, this constitutes a structural feature of the European Union. The changes that have evolved along different paths have different implications for the European polity as such. The bargaining-oriented escape routes seeking compensation, the use of issue-linkage and package deals - are chosen with the full knowledge of those concerned and indeed, they normally provide means of overcoming an imminent decision-making gridlock under conditions of lesser diversity than those which currently exist in the European polity. They constitute a normal means of oiling the wheels of democratic decision-making processes under conditions of diversity. The same holds true for the type of soft strategy which seeks to increase the transparency of European policy-making by facilitating mutual control on the basis of a well-balanced representation of diverse interests, and building supportive networks which are structurally unbiased. By contrast, a candidate for reform would be covert modes of institutionalization which involve an element of stealth or surprise for those involved, in the sense that they are inadvertently brought into situations where they are forced to pursue a route of action that they did not want to embark on in the first place. For unlike the first two modes of overt institutionalization, the covert mode of policy-making constitutes a way of circumventing deadlock which contradicts two important principles of institutions, that of being known and accepted by all the parties concerned, and of being based on shared expectations about appropriate behaviour. Instead, this type of overt and covert institutionalization is surreptitious by nature and remains a grey area of unofficial short-cuts; it thrives on and seeks to exploit uncertainty, and is concealed from general public scrutiny. 
Finally, the question emerges as to whether overt and covert institutionalization occurs under any conditions, or whether there are instances in which this type of escape route is not chosen and does not take place. Such conditions do indeed exist. The first is, of course, when there is no deadlock situation in the first place and member states agree to take specific policy steps to enlarge the scope of European activities. This condition arises in a situation where all stand to win from co-operation and, as a consequence, there is wide domestic support for the proposed policy. What happens more frequently, however, is that member states agree not to take policy steps, and pull out of a specific policy area altogether, because some players would suffer a loss from the decision. This tends to be the case when a redistributional issue is at stake and important domestic alliances within member states oppose the proposed decision. The outspoken refusal to adopt a European policy may also be the result of member states' governments learning from the experience of overt and covert institutionalization and explicitly seeking to prevent policy expansion in a specific area, such as was done by exempting the Third Pillar from the jurisdiction of the ECJ. De-institutionalization, as it were, may occur in the form of offering single member states possibilities for opting out, or by deciding to end a programme at the European level altogether, thus leaving activities to individual member states. The possibility of opting out is illustrated by the example of social policy (Rhodes 1995). New institutional avenues were sought and found under the Social Protocol in the Maastricht negotiations: opting out and twin-track policy-making. Since it seemed highly likely that Britain would be prepared to block changes to the Treaty through its use of the veto, an escape route to circumvent the deadlock emerged 'through the most unusual and unpredictable of compromises' (Lange 1992: 249). The other eleven member states signed a separate protocol that allows them to use EC 'institutions, procedures and mechanisms' to formulate and implement social policies on which they agree. In order to accommodate the diverse views, they went outside the Treaty, i.e. provisions passed under the Social Protocol did not require enactment by Britain, which has an optout option. As far as active social policy-making was concerned therefore, the looming deadlock was avoided by the creation of a twin-track institutional process. Monetary union and the Schengen Agreement are further examples where not all member states formally adopt a new policy, but remain outside it instead.

The other form is where European policy measures are brought to an end altogether. Thus, in the case of European anti-poverty policy, member states decided at one point not to pursue the antipoverty programme. As we have seen, however, the Commission ignored this intention and sought to continue the programme by other means. Another example is in the area of social insurance where the Court decided on the "portability" of insurance rights of migrant workers within the Community. Recently member states have sought to overturn the Court's ruling on co-ordination in portability. They have unanimously agreed to decisions that allow member states to restrict the granting of benefits rights after proper notification, which in turn is subject to the unanimous approval of member states. So far there has been an informal agreement to allow such self-exemptions (Leibfried and Pierson 1995:64). It may well be that with a range of new members joining the Community and diversity deepening even further, this reverse route of opting out and unanimous refrain from widening the scope of European policy-making becomes more frequent. 


\section{References}

Bates, Robert H. 1988. Contra Contractarianism: Some Reflections on the New Institutionalism. Politics and Society 16: 387-401.

Bauer, Michael W. 1999. The Commision and the Poor. Some Preliminary Lessons drawn from a Case Study on the EU Poverty Programmes.

Brunsson, Nils. 1989. The Organization of Hypocrisy. Talk, Decisions and Actions in Organizations. Chichester: Wiley \& Sons.

Calvert, Randall L., and Jim Johnson. 1998. Interpretation and Coordination in Constitutional Politics. Working Paper no. 15, University of Rochester.

Demsetz, Hugh. 1988. Ownership, Control and the Firm. Oxford: Basil Blackwell.

Egan, Michelle. 1998. Constructing a European Market: Trade Barriers, Regulatory Strategies and Corporate Responses. Unpublished ms. American University.

Fligstein, Neil. 1997. Markets, Politics and Globalisation. Uppsala: Uppsala University Press.

Héritier, Adrienne. 1999. Policy-Making and Diversity in Europe. Escaping Deadlock. Cambridge: University Press.

1997. Policy-Making by Subterfuge: Interest Accommodation, Innovation and Substitute Democratic Legitimation in Europe - Perspectives From Distinctive Policy Areas. Journal of European Public Policy 4: 171-89.

Héritier, Adrienne, Christoph Knill, and Susanne Mingers. 1996. Ringing the Changes in Europe: Regulatory Competition and the Transformation of the State: Britain, France, Germany. Berlin, New York: de Gruyter.

Knight, Jack. 1992. Institutions and Social Conflict. Cambridge: Cambridge University Press. 1995. Models, Interpretations, and Theories: Constructing Explanations of Institutional Emergence and Change. In J. Knight and I. Sened, eds. Explaining Social Institutions. Ann Arbor: The University of Michigan Press: 95-120.

Knight, Jack, and Jim Johnson 1994. Aggregation and deliberation: on the possibility of democratic legitimacy. Political Theory 22: 277-296.

Knight, Jack, and Itai Sened, eds. 1995. Explaining Social Institutions. Ann Arbor: The University of Michigan Press.

Lange, Peter. 1992. The Politics of the Social Dimension. In A. Sbragia, ed. Euro-Politics: Institutions and Policymaking in the"New" European Community. The Brookings Institution.

Leibfried, Stephan, and Paul Pierson, eds. 1995. European Social Policy. Between Fragmentation and Integration. Washington D.C.: The Brookings Institution. 
Majone, Giandomenico. 1998. Europe 'democratic deficit': the question of standards. European Law Journal 4: 5-28.

Majone, Giandomenico. 1995. Independence and accountability: non-majoritarian institutions and democratic government in Europe. In J. Weiler, R. Dehousse and A. Cassese, eds. Collected Courses of the Academy of European Law. London: Routledge.

Marks, Gary, Liesbet Hooghe, and Kermit Blank. 1996. European integration from the 1980s: statecentric v. multi-level governance. Journal of Common Market Studies 34: 341-378.

Mayntz, Renate. 1993. Policy-Netzwerke und die Logik von Verhandlungssystemen. In A. Héritier, ed. Policy-Analyse. Kritik und Neuorientierung. Politische Vierteljahresschrift Sonderheft 24.

North, Douglass C. 1995. Five Propositions About Institutional Change. In J. Knight and I Sened, eds. Explaining Social Institutions. Ann Arbor: The University of Michigan Press: 15-26.

Rhodes, Martin. 1995. A Regulatory Conundrum: Industrial Relations and the Social Dimension. In S. Leibfried and P. Pierson, eds. European Social Policy: Between Fragmentation and Integration. Washington D.C.: The Brookings Institution: 78-122.

Riker, William H. 1996. The Strategy of Rhetoric. Campaining for the American Constitution. New Haven \& London: Yale university Press.

Sandholtz, Wayne, and Stone Sweet, Alec. 1998. European integration and supranational governance. Oxford: Oxford University Press.

Scharpf, Fritz W. 1999. Governing in Europe: Effective and Democratic. Oxford University Press.

Scharpf, Fritz. W. 1997b. The problem-solving capacityof multi-level governance. Journal of European Public Policy 4: 520-38.

Schelling, Thomas C. 1963. The Strategy of Conflict. New York: Oxford University Press.

Schmidt, Susanne. 1995. The Integration of the European Telecommunication and Electricity Sectors in the Light of International Relations Theories and Comparative Politics. Paper ECPR Joint Sessions of Workshops. Bordeaux.

Shapiro, Martin. 1968. The Supreme Court and Administrative Agencies. Free Press: CollierMacmillan.

Sweet Stone, Alec. 1999. Judicialization and the construction of governance. Comparative Political Studies 32: 147-183.

Sweet Stone, Alec, and Thomas L. Brunell. 1998. Constructing a Supranational Constitution: Dispute Resolution and Governance in the European Community. American Political Science Review 92: 63-82.

Sweet Stone Alec, and Jim A. Caporaso. 1998. La Cour de justice et l'intégration européenne. Revue française de science politique 48: 195-244.

Windhoff-Héritier, Adrienne. 1987. Policy-Analyse. Eine Einführung. Campus Verlag. 